\title{
Study of rape cases history attended at tertiary centre
}

\author{
Sujata Pavan Jadhav
}

Associate Professor, Department of Obstetrics and Gynaecology, JIIU'S IIMSR Warudi Taluka Badnapur Dist Jalna, Maharashtra, INDIA. Email: drsujatajadhavmax@gmail.com

Abstract Background: Rape is a crime not just against a single person but against the entire humanity. According to the American Medical Association rape is the most underreported crime in the world. Aims and Objective :To Study rape cases history attended at tertiary centre. Methodology: This was a cross-sectional study carried out in the Rape cases reported at the Department of OBGY of a tertiary health care centre during the one year period i.e. April 18 to April 19. In the one year period with written and explained consent 23 cases enrolled into the study. All Important details like, Age, Type rape, Socioeconomic Class and Gynecological examination was carried out .These details were entered to excel sheet and analyzed by excel software for windows 10. Results: In our study we have found that The majority of the cases were of only rape i.e. $69.57 \%$ and Kidnapping and Rape were $30.43 \%$. The most common duration between rape and reporting was $>1$ months i.e. in $47.83 \%$ followed by 1 week to month were $17.39 \%$; Within 24 hour were $13.04 \%$; 24-48 hours $-13.04 \%$; Within 1 week were $8.70 \%$. The majority of the cases were of the Low income Socio Economic class i.e. $78.26 \%$ and Middle Were $21.74 \%$ and no cases was reported of higher Socio Economic class. On Gynecological examination the majority of the cases were Habitual to intercourse i.e. $56.52 \%$ and true rape was found in $43.48 \%$. It indicates that the majority of the sexual violence was done by known person as the gynecological examination revealed majority having Habitual to intercourse it indicates that the rape may be false promise of marriage. Conclusion: It can be concluded from our study the majority of the victims were adult, majority were having the lower Socio economic class, most of the victims were having habituated intercourse indicates the crime may be occurred because of false promises of marriage and the reporting time was more than 1 month so the reporting time should be reduced for prevention of complication and accurate evidence generation.

Key Word: rape case.

\section{*Address for Correspondence:}

Dr Sujata Pavan Jadhav, Associate Professor, Department of Obstetrics and Gynaecology, JIIU'S IIMSR Warudi Taluka Badnapur Dist Jalna, Maharashtra, INDIA.

Email: drsujatajadhavmax@gmail.com

Received Date: 09/12/2020 Revised Date: 10/01/2020 Accepted Date: 05/02/2020

DOI: https://doi.org/10.26611/101215310

This work is licensed under a Creative Commons Attribution-NonCommercial 4.0 International License. (cc)) EY-NC

\begin{tabular}{|l|l|}
\hline \multicolumn{2}{|c|}{ Access this article online } \\
\hline Quick Response Code: & Website: \\
& www.medpulse.in \\
\hline & \\
\hline
\end{tabular}

\section{INTRODUCTION}

Rape is a crime not just against a single person but against the entire humanity. According to the American Medical Association rape is the most underreported crime in the world ${ }^{1}$. Most of the studies highlight the fact that the number of cases reported to the casualty for medical care and evidence collection is just the tip of the ice berg ${ }^{2}$ Though the problem of rape is considered serious in all countries, in India it is statistically not as serious as it is in the western society (Crime in India, 2002) ${ }^{3}$. Data for rape cases has been collected by the National Crime Records Bureau in India since 1971, while data on other crimes is available from 1953 (National Crime Record Bureau, 2008). The National Crime Record Bureau and the Police Research Institutes were not in a position to provide any information other than some numerical data, based mostly on self approached cases, which are recognized to be highly under-reported (Society for Development Studies, $2009)^{4}$, So we have studied the rape cases at tertiary centre. 


\section{METHODOLOGY}

This was a cross-sectional study carried out in the Rape cases reported at the Department of OBGY of a tertiary health care centre during the one year period i.e. April 18 to April 19. In the one year period with written and explained consent 23 cases enrolled into the study. All Important details like, Age, Type rape, Socioeconomic Class and Gynecological examination was carried out. These details were entered to excel sheet and analyzed by excel software for windows 10 .

\section{RESULTS}

Table 1: Age wise Distribution of the rape cases

\begin{tabular}{ccccc}
\hline Age & $\begin{array}{c}\text { Kidnapping and } \\
\text { Rape }\end{array}$ & Rape & Total & $\begin{array}{c}\text { Percentage } \\
(\%)\end{array}$ \\
\hline $\mathbf{1 0 - 1 2}$ & - & - & - & - \\
$\mathbf{1 3 - 1 6}$ & 5 & 4 & 9 & 39.14 \\
$\mathbf{1 7 - 1 9}$ & 2 & 12 & 14 & 60.86 \\
\hline Total & 7 & $\mathbf{1 6}$ & $\mathbf{2 3}$ & $\mathbf{1 0 0 . 0 0}$ \\
\hline
\end{tabular}

The majority of the cases were in the age group of 17-19 were $60.86 \%$ followed by $13-16$ were $39.14 \%$.

Table 2: Distribution of the cases as per the Rape as Gynecological problem

\begin{tabular}{ccc}
\hline & No. & Percentage (\%) \\
\hline Kidnapping and Rape & 7 & $30.43 \%$ \\
Only Rape & 16 & $69.57 \%$ \\
\hline
\end{tabular}

The majority of the cases were of only rape i.e. $69.57 \%$ and Kidnapping and Rape were $30.43 \%$.

Table 3: Distribution of the patients as per the duration between rape and reporting

\begin{tabular}{ccc}
\hline $\begin{array}{c}\text { Duration between rape and } \\
\text { reporting }\end{array}$ & No. & Percentage (\%) \\
\hline Within 24 hour & 3 & $13.04 \%$ \\
24-48 hours & 3 & $13.04 \%$ \\
Within 1 week & 2 & $8.70 \%$ \\
1 week to month & 4 & $17.39 \%$ \\
$>$ 1months & 11 & $47.83 \%$ \\
\hline
\end{tabular}

The most common duration between rape and reporting was $>1$ months i.e. in $47.83 \%$ followed by 1 week to month were $17.39 \%$; Within 24 hour were 13.04\%; 24-48 hours $13.04 \%$; Within 1 week were $8.70 \%$.

Table 4: Distribution of the patients as per the Socio Economic

\begin{tabular}{ccc}
\multicolumn{3}{c}{ class } \\
\hline Socio Economic class & No. & Percentage (\%) \\
\hline Low & 18 & $78.26 \%$ \\
Middle & 5 & $21.74 \%$ \\
Higher & 0 & $0.00 \%$ \\
\hline
\end{tabular}

The majority of the cases were of the Low income Socio Economic class i.e. $78.26 \%$ and Middle were $21.74 \%$ and no cases was reported of higher Socio Economic class.
Table 5: Distribution of the patients as per the Conclusion on

\begin{tabular}{ccc}
\multicolumn{3}{c}{ History Examination } \\
\hline & No. & Percentage (\%) \\
\hline True Rape & 10 & $43.48 \%$ \\
Habitual to intercourse & 13 & $56.52 \%$ \\
\hline Total & 23 & $100.00 \%$ \\
\hline
\end{tabular}

On Gynecological examination the majority of the cases were Habitual to intercourse i.e. $56.52 \%$ and true rape was found in $43.48 \%$.

\section{DISCUSSION}

Sex related offence has remained a menace to the society since long times. Whatever be the circumstances, sexual crimes create a lifelong scar in the mental set up of the victims, as well as to the relatives of victim. The popular belief in the society that only women are subjected to sexual cruelty and harassment is no longer truth as incidence with young male victims are also common. Whenever an allegation of sex related crime is made the first question which comes to mind of the investigators is whether it is at all true or a false charge. Moreover sex related crimes are one of the most underreported crimes. According to a study of RAINN $\left[^{5}\right] 54 \%$ of sexual assaults are not reported to the police, $97 \%$ of rapists will never spend a day in jail and multiple instances of commission of the assault on single women are also common. Despite the advancement of medical technology and even when meticulous clinical examination is done, the importance of circumstantial evidence can never be undermined ${ }^{6}$. Sexual assault is an evil trend on women since long in society, young girls and children are most vulnerable to this heinous crime which has recently increased in number over a decade ${ }^{7}$. Rape is among the most underreported crime on women in all section of the society it is a big challenge to obtain an accurate measurement of sexual assault. Rape is defined in India as intentional, unlawful sexual intercourse with a woman without her consent. The essential elements of this definition under Section 375 of the Indian Penal Code are ,sexual intercourse with a womane and the absence of consent. This definition therefore does not include acts of forced oral sex, or sodomy, or penetration by foreign objects; instead those actions are criminalized under Section 354 of the IPC, which deals with ,criminal assault on a woman with intent to outrage her modesty and Section 377 IPC, covering „,carnal intercourse against the order of nature ${ }^{\text {ee }}{ }^{8}$ Although sexual assaults most frequently are by a man on a woman, it may involve any combination of two or more men, women and children. To provide a safe environment to victim, a big initiative is taken from government of India to provide all necessary care and legal formalities under one roof i.e. One Stop Centre. Ministry of Women and Child Development (MWCD), has formulated a Centrally 
Sponsored Scheme for setting up One Stop Centre, a subscheme of Umbrella Scheme for National Mission for Empowerment of women including Indira Gandhi Mattritav Sahyaog Yojana. These Centres will be established across the country to provide integrated support and assistance under one roof to women affected by violence, both in private and public spaces in phased manner $\left({ }^{9}\right.$. Sexual violence has generally been a neglected area and less discussed issue of research in most part of the world specially in developing countries here it is considered as big stigma women feel ashamed in herself and remain in guilt. Women most of the time doesn ${ }^{\text {ee }} t$ reveal in front of anyone. Evidence suggest that it is a public health problem of substantial proportion there is lot of scope to understand the phenomenon and to prevent it. ${ }^{10,11}$ Most health care interventions can only be delivered when the survivors present in the first one to five days of sexual assault to prevent complications. However, studies in developing countries have shown that this effective widow for intervention is usually delayed by 18.4 days 12,13 , compared to the median time from onset of assault to presentation of 16 hours in USA. About one fourth of victims presented within 4 to 7 days after the sexual assault. However, many victims have delayed presentation at One Stop Crisis Centre which may be due to threat from perpetrator, financial constraint, abduction, lack of services and apathetic attitude of caregivers. In our study we have found that The majority of the cases were of only rape i.e. $69.57 \%$ and Kidnapping and Rape were 30.43\%. The most common duration between rape and reporting was $>1$ months i.e. in $47.83 \%$ followed by 1 week to month were $17.39 \%$; Within 24 hour were 13.04\%; $24-48$ hours $13.04 \%$; Within 1 week were $8.70 \%$. The majority of the cases were of the Low income Socio Economic class i.e. $78.26 \%$ and Middle Were $21.74 \%$ and no cases was reported of higher Socio Economic class. On Gynecological examination the majority of the cases were Habitual to intercourse i.e. $56.52 \%$ and true rape was found in $43.48 \%$. It indicates that the majority of the sexual violence was done by known person as the gynecological examination revealed majority having Habitual to intercourse it indicates that the rape may be false promise of marriage. These findings are similar to Puneeta Mahajan 14 they found Commonest age group of affected victims was $11-20$ years $(44.53 \%)$. Most of them were educated up-to 12th standard (26.3\%). Majority of victim were students $(34.26 \%)$. Victim's house was found to be most common place for offence which accounts for $28.25 \%$ of cases. Boyfriend was found to be most common offender (35.7\%). Majority of the victim (25.69\%) came between 4 thto 7 thday after sexual assault for examination

\section{CONCLUSION}

It can be concluded from our study the majority of the victims were adult, majority were having the lower Socio economic class, most of the victims were having habituated intercourse indicates the crime may be occurred because of false promises of marriage and the reporting time was more than 1 month so the reporting time should be reduced for prevention of complication and accurate evidence generation.

\section{REFERENCES}

1. American Medical Association (1995) Sexual Assault in America. AMA.

2. http://www.statisticbrain.com/rape-statistics/

3. Crime in India, (2002). National Crime Record Bureau, Ministry of Home Affairs, New Delhi.

4. Society for Development Studies, (2009). Women Safety in Delhi -Report to Ministry of Women and Child Development. New Delhi.

5. Rape Abuse and Incest National Network [Online] Available from http://www.rainn.org/statistics dated 18/4/2013

6. Soumyajyoti Bandyopadhay ,Somanjana Ghosh et al.. A Study on Sexual Assault Victims Attending a Tertiary Care Hospital of Eastern India. Volume 6, Issue 6 (May.- Jun. 2013), PP 16-19

7. B. L. Himandu. Radhika Arora. N.S. Prashanth, Whose problem is it anyway? Crimes against women in India. Global Health Action. July 2014, 7:10.3402

8. K. Kannan. K. Mathiharan, Sexual offences, Modi- A textbook of medical Jurisprudence and toxicology, 24th Edition, Chapter 31, 637-638

9. One Stop Centre scheme, Implementation guidelines, Ministry of women and child development, Government of India, August 2016

10. Kumar Pal. Sharma A. A study of sexual assaults in Northern range of Himachal Pradesh, International Journal of medical toxicology and Forensic medicine 2015; 5(2); 64-72

11. Soumyajyot., Somanjana Ghosh, A study on sexual assault victims attending a tertiary care hospital of East India, IOSR Journal of Dental and medical sciences,May 2013;6;16 -19

12. Robert Lalasz. Profiling Domestic violence: A Multicountry study, ORC Macro, September 2004 [10] 13. Nicholas Kristof. A reason not to report rape, New York Times, 1st May 2009

13. Puneeta Mahajan, Vinita Gupta. Sexual Assault: Analysis in a District Hospital fromNorth India. Journal of Dental and Medical Sciences (IOSR-JDMS). .Volume 17, Issue 3 Ver.17 March. (2018), PP 42-46.

Source of Support: None Declared Conflict of Interest: None Declared 